



\section{El cuerpo como posibilidad informativa, reflexiva y creativa}

Patricio Rodríguez-Plaza*

¿Es el cuerpo efectivamente un envoltorio de algo más que sus propios límites carnales, que pueda sorprendernos todavía desde la perspectiva de las experiencias artísticas? ¿Existirá el alma como una dimensión necesariamente trascendente respecto de esto que en nuestras lenguas romances llamamos, siguiendo al latín, corpus? ¿Es el cuerpo la literal o la metafórica encarnación de los sentidos, que ubicados más allá de su materialidad, solo instrumentalizan temporalmente las expresiones creativas?

Sea como fuere, el cuerpo es para las artes del espectáculo y las teatralidades, el elemento que les permite aun existir. No solo su fundamento, sino también su razón de ser, la exclusiva manera de acercarse a la expresión y a la experiencia estética. En este sentido las preguntas iniciales o son inconducentes o están mal formuladas, en cuanto ellas responden a la inalcanzable necesidad de conjurar a la única realidad a la que responde el cuerpo en su finitud: la muerte.

\footnotetext{
*Patricio Rodríguez-Plaza es investigador e profesor de la Escuela de Teatro y del Magíster en Artes de la Facultad de Artes de la Pontificia Universidad Católica de Chile. Es el autor de Estética urbana y mayorías latinoamericanas (Santiago de Chile: Ocho Libros Editores, 2011) e de La pintura callejera chilena: manufactura estética y provocación teórica (Santiago de Chile: Ocho Libros Editores, 2011). Es el director de la Revista Cátedra de Artes.
} 
El presente dossier, luego, se articula en dos ejes que manteniendo sus especificidades, logra una coherencia obligada, entregada por las vías discursivas que literalmente atraviesan ciertos campos semánticos, profesionales y artísticos. Dossier integralmente a cargo de profesores de la Facultad de Artes de la Pontificia Universidad Católica de Chile.

\begin{abstract}
Una vía está dada por un trabajo teórico y conceptual a cargo de María José Contreras, quien pasa revista a distintas maneras de entender al cuerpo como un camino excepcional y derecho de conocimiento. En un trabajo narrativo de alto alcance, este texto asume las implicancias epistémicas y hasta políticas sobre las cuales se ha comenzado a indagar el cuerpo no solo como objeto de conocimiento, sino, y sobre todo, como configuración de entendimiento y activamiento de las facultades sensoriales a través de las cuales los seres humanos nos conectamos con la realidad y la creación.
\end{abstract}

Una segunda vía propone los textos de los actores y académicos Alexei Vergara Aravena y Daniel Gallo Orrego, en donde cada uno y a su manera, nos entrega pistas de reflexión en relación al cuerpo como aparato y programa de realidades dramatúrgicas válidas como formas de creación estructurada y estructurante.

El primero se sitúa en el ámbito vasto y complejo de la enseñanza en una escuela de teatro, en donde el cuerpo es menos un instrumento a utilizar que una encrucijada cultural. Así, el profesor Vergara Aravena entabla una narración que informa y expone la tradición de un curso educativo formal llamado "Percepción Actoral," cuyo derrotero esencial es justamente la percepción en tanto posición y fundamentación pedagógica y creativa. Percibir, como se nos ha enseñado, es más que ver, oír o tocar, que son algunas de las experiencias a través de las cuales los sentidos crean sentido. Pero también percibir es una actividad intrínsecamente corporal y material, sin cuyos medios esta no existe más que como una expresión sin sustento ni anclaje. 
En cuanto al texto de Gallo Orrego, se trata de una exploración con ribetes de introspección poética y teatral, en cuyo centro se sitúa la exposición de la necesidad de conceptualizar el arduo trabajo que le permite a un actor pensar y articular su quehacer. Esto en una obligada entremezcla entre aquello que siguiendo a Eugenio Barba podría ser su personalidad, la tradición y el contexto histórico-cultural a través del cual esa personalidad se manifiesta y la fisiología según técnicas corporales extra-cotidianas que le permiten sus resultados profesionales. La noción que guía y acompaña esta exploración es justamente la de lo literal como forma y herramienta de hacer efectivo un trabajo de relación creativa entre realidad, acción actoral y construcción de personaje.

Finalmente se debe señalar que las imágenes que completan este dossier corresponden a una intervención virtual hecha por Helena Panussis sobre un registro de video y fotografía de Claudia Sanhueza y Michèlle Piaggio del trabajo performático de la artista Sybil Brintrup; trabajo titulado Acción Pública Pública, realizado en el marco de la $11^{\text {a }}$ Bienal de Artes Mediales y presentado in situ en el Museo Nacional de Bellas Artes de Santiago de Chile en octubre de 2013.

Brintrup se ha caracterizado por la realización de una obra ardua y regular respecto de la voz, de la escritura, de la significación que posibilitan los sonidos y las palabras en su configuración tipográfica, gutural, sonora, corporal. Todo ello, esta vez, aludiendo al quehacer doméstico del planchado de ropa asumido por la acústica de un edificio, que desde más de 100 años, almacena unas obras de renombre, obliterando con ello las otras miles de voces creativas dispersas en el ámbito de lo social.

De este modo los distintos caminos presentados en este espacio de Poiesis vuelven a temas recurrentes respecto del cuerpo expresivo, artístico, estético o performativo, que no por serlos, han perdido vigencia o han agotado sus rugosidades expresivas. 
Agradecemos al profesor Luiz Sérgio de Oliveira por la invitación que nos ha posibilitado la realización de este dossier, el cual contó a su vez con la participación profesional de la coordinadora editorial de Cátedra, profesora Bernardita Abarca Barboza. 